doi: $10.5937 /$ SelSem1801001M

\title{
EFFECT OF SOWING DATE ON DRY MATTER ACCUMULATION IN TWO-ROWED WINTER BARLEY
}

\author{
Milan Mirosavljevići ${ }^{*}$, Vojislava Momčilović ${ }^{1}$, Ivana Maksimović ${ }^{2}$ \\ Marina Putnik-Delić ${ }^{2}$ Ljiljana Brbaklić́ ${ }^{1}$, Novo Pržulj ${ }^{3}$
}

\begin{abstract}
Information about dry matter accumulation is of great importance for further increase of barley yield. Various nonlinear and linear curves have been used to describe vegetative and reproductive growth for a number of agricultural crops. Although dry matter accumulation is an important parameter of crop growth, knowledge about biomass production under agro-ecological conditions of the Pannonian Plain are scarce. This study was undertaken to analyze the pattern of dry matter accumulation in two-rowed winter barley cultivars and changes in biological parameters of the logistic curve under different sowing dates and growing seasons. Therefore, trials with two late cultivars of two-rowed winter barley were conducted in two growing seasons and four sowing dates. Results from this study indicate that dry matter accumulation in both growing seasons followed a typical sigmoid shape. Delayed sowing led to a significant decrease in the maximum value of plant dry weight, the termal time needed to reach maximum value and duration of exponential growth, and increase in maximum crop growth rate. These results indicate that apart from appropriate cultivar selection, early barley sowing is also important to achieve high plant dry matters one of the main determinants of grain yield.
\end{abstract}

Key words: biomass, Hordeum vulgare, logistic curve, planting time

\section{Introduction}

Dry matter accumulation is the final product of crop photosynthetic activity throughout the entire growing season. Moreover, dry matter stored in the vegetative plant parts during the pre-anthesis period is important for grain growth, especially under less favorable environmental conditions. The interest of the breeding studies was mainly related to the formation of high and stable grain yield (Petrović et al., 2013; Banjac et al., 2015), and less attention was paid to crop development and growth, especially during the period prior to anthesis. As previously reported (Pržilj and Momčilović, 2002; Pržulj and Momčilović, 2011), pre-anthesis crop development significantly affects the potential grain yield. For example, leaf and spikelet primordia are formed during the period from emergence to stem elongation, while the number of fertile stems and florets is determined during stem elongation period (Slafer, 2003).

\footnotetext{
Orginalni naučni rad (Original scientific paper)

${ }^{1}$ Mirosavljević M*, Momčilović V, Brbaklić Lj, Institute of Field and Vegetable Crops, Serbia.

${ }^{2}$ Ivana Maksimović I, Putnik-Delić M, Faculty of Agriculture, University of Novi Sad, Serbia

${ }^{3}$ Pržulj N, University of Banja Luka, Bosnia and Herzegovina

*e-mail: milan.mirosavljevic@nsseme.com
} 
A significant association between grain yield and dry matter at anthesis or during grain filling was recorded in wheat (Turner, 1997) and barley (Mirosavljević et al., 2015). The yield increase in the previous 50 years was mainly related to the changes in assimilates distribution of the plants, and modern cultivars of different cereal crops have already reached high values of the harvest index. The absence of significant changes in plant dry matter at physiological maturity showed that the canopy traits associated with radiation use efficiency did not change significantly during the development of new cultivars (Araus et al., 2008). Accordingly, further increase in grain yield should be achieved by developing new cultivars with the higher dry matter at anthesis and maturity, while maintaining high values of the harvest index (Zhou et al., 2014).

According to the previous studies (White et al., 2011; White et al., 2012), sowing date (SD), as a special combination of different temperature and photoperiod regimes, significantly affects crop development, final leaf number, phyllochron and the duration of different phenological phases. By changing the duration of the period from emergence to anthesis (Ehdaie and Waines, 2001) and environmental conditions during the grain filling period ( $\mathrm{Pa}$ nozzo and Eagles, 1999; Subedi et al., 2007), the sowing date can significantly modify the accumulation and contribution of dry matter and nitrogen in grain weight and yield.

Although dry matter production is one of the best indicators of crop response to the influence of genotypic and environmental factors, there is a lack of information about dry matter accumulation in barley under different agro-ecological conditions of the Pannonian Plain, such as sowing dates. Therefore, the aim of this study was to examine the dry matter accumulation in two-rowed winter barley, as well as to determine the relationship of logistic curve parameters in the determination of final dry matterunder conditions of different sowing dates and growing seasons.

\section{Materials and methods Treatments}

The trial was carried out at the experimental field Rimski Šančevi of the Institute of Field and Vegetable Crops, Novi Sad, Serbia $\left(19^{\circ} 51^{\prime} \mathrm{E}, 45^{\circ} 20^{\prime} \mathrm{N}\right)$. The experiment with two cultivars of winter barley (Cordoba and Greval) was carried out during two growing seasons (2013/14 and 2014/15). Sowing dates (SD) were $27^{\text {th }}$ September 2013 and $28^{\text {th }}$ September 2014 (SD1); $11^{\text {th }}$ October 2013 and $11^{\text {th }}$ October 2014 (SD2), 25 $5^{\text {th }}$ October 2013 and $25^{\text {th }}$ October 2014 (SD3), and $8^{\text {th }}$ November 2013 and $6^{\text {th }}$ November 2014 (SD4). Sowing rate was 350 germinable grains per $\mathrm{m}^{2}$ (recommended rate for field scale production). The plots were $1 \mathrm{~m}$ wide and $5 \mathrm{~m}$ long, with 0.1 $\mathrm{m}$ spacing between rows. All trials were fertilized in doses consistent with good agricultural practice, based on agrochemical analysis of the soil. Pests and diseases were prevented or controlled by spraying the recommended fungicides and insecticides, and weeds were periodically removed by hand. No artificial irrigation was applied.

\section{Measurements}

In order to determine dry matter accumulation in barley cultivars, the above-ground parts of five plants were sampled in the interval from 4 to 7 days from the appearance of the second leaf to physiological maturity.The samples were taken from the central rows and consisted of five plants per replication. After drying at $80^{\circ} \mathrm{C}$ for a minimum of 48 hours, the dry matter content was measured. 
Daily maximum $\left(\mathrm{T}_{\max }\right)$ and minimum $\left(\mathrm{T}_{\text {min }}\right)$ air temperatures were obtained from a meteorological station located at the experimental field. Daily mean air temperature was calculated as $\mathrm{T}=0.5 \times\left(\mathrm{T}_{\max }+\mathrm{T}_{\min }\right)$ using a base temperature of $0^{\circ} \mathrm{C}\left({ }^{\circ} \mathrm{Cd}\right)$.

\section{Data analysis}

Considering the similar growing period of the barley cultivars, dry matter accumulation was shown as an average value of cultivars. Dry matter accumulation data were fitted to the logistic curve:

$$
y=y_{\text {asym }} /\left(1+e^{-k\left(t-t_{\text {inf }}\right)}\right)
$$

where $y$ is the estimated crop dry matter, $y_{\text {asym }}$ is the asymptotic $\mathrm{Y}$ value, $\mathrm{t}$ is the time from emergence calculated in growing degree days, $t_{\text {inf }}$ is the inflection point at which growth is maximized, $\mathrm{k}$ controls the steepness of the curve. Curve characteristics with biological meaning (the maximum value of plant dry weight $-y_{\max }$, thermal time needed to reach $\mathrm{y}_{\max }-\mathrm{x}_{\max }$, the duration of exponential growth- DUR and maximum crop growth rate- $\mathrm{Cm}$ ) were calculated according to Villegas et al. (2001) and Munakamwe et al. (2014).

Data were subjected to analysis of variance and differences between sowing dates were tested using Tukey test $(\mathrm{P}<0.05)$. The nonlinear equations were calculated using Curve Expert Professional (Trial version), while Infostat (student version) was used for analysis of variance.

\section{Weather conditions}

Weather data (precipitation and air temperatures) were obtained from a meteorological station situated at the same location where the trial took place and reported for 2013/14 and 2014/15 growing seasons (Figure 1).

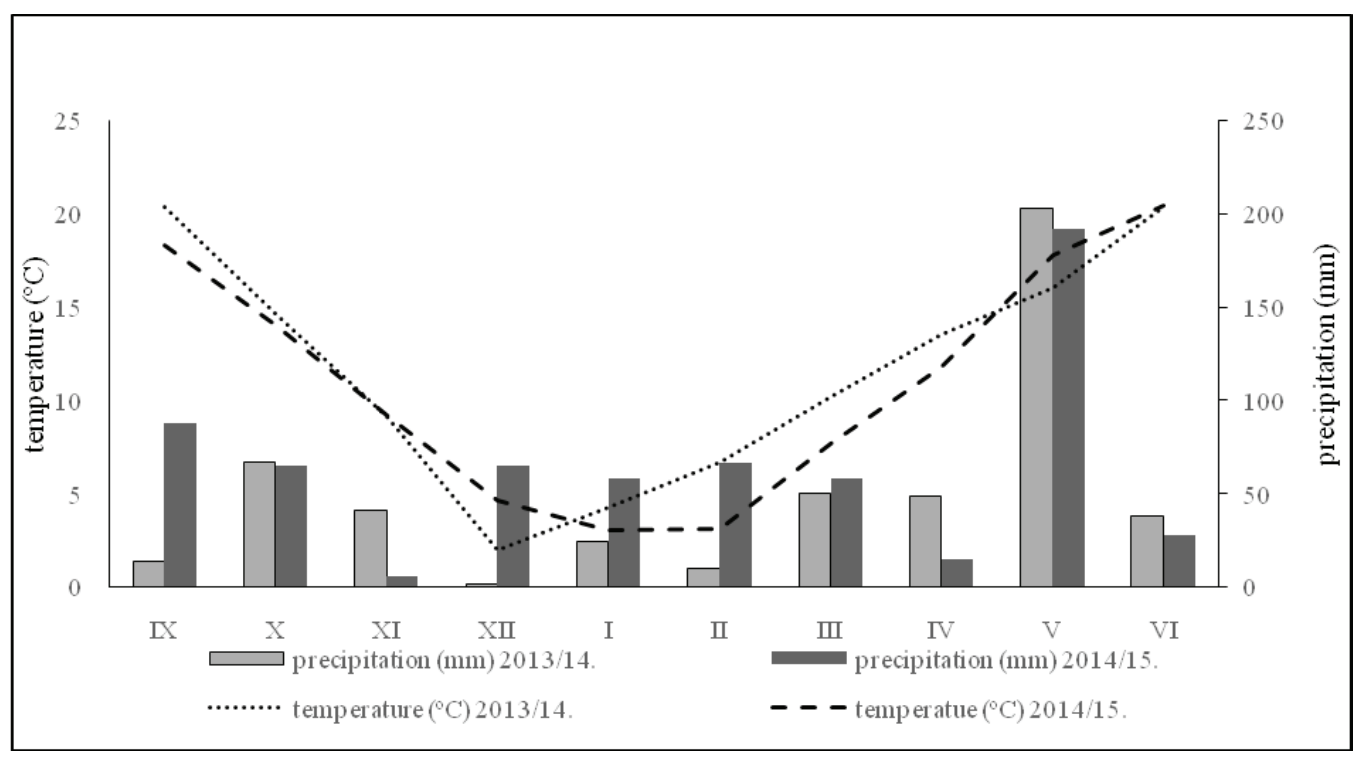

Figure 1. Monthly average temperature and precipitation for the growing seasons 2013/14 and 2014/15 Grafikon 1. Prosečne mesečne padavine i temperatura u sezonama 2013/14. i 2014/15. 
The amount and distribution of precipitation, as well as the average daily temperatures, varied considerably between the growing seasons. Weather conditions for the season 2013/14 were characterized by higher precipitation and more favorable temperatures for crop development in October and November. From December to March precipitation was extremely low, reducing the winter moisture reserves in the soil and having a negative effect on further crop development in spring. In 2014/15, lower temperatures were recorded in spring and increased precipitation in winter and filling period than in 2013/14. Also, precipitation was more equally distributed in 2014/15 than in the previous season.

\section{Results and discussion}

The results of this study show that dry matter accumulation in barley plants followed a typical sigmoidal pattern in both growing seasons (Figure 2). The values of $\mathrm{R}^{2}$ coefficients, which were generally above 0.97 (Table 1 ), indicate that dry matter accumulation has been well explained with a logical equation. Although sigmoidal curves are most commonly used to describe the accumulation of dry matter during growing season or the grain filling period, some authors reported that polynomial equations can also be used. For example, Malhi et al. (2007) proposed the use of a third-degree polynomial to describe the growth of peas and lentil. One of the problems with this approach is the selection of the appropriate polynomials to describe plant growth (Yin et al., 2003). The logistic equation is widely used to describe the accumulation of dry matter in different crops. According to Yang et al. (2011), dry accumulation of cotton during the season could be described by the logistic curve. In addition, the logistic curve was used to describe changes in the soybean leaf index (Setiyono et al., 2008). Moustakas and Ntzanis (2005) stated that the accumulation of dry matter in the leaves, stem, root and aboveground parts of the tobacco plant during the growing season followed a typical sigmoidal pattern.
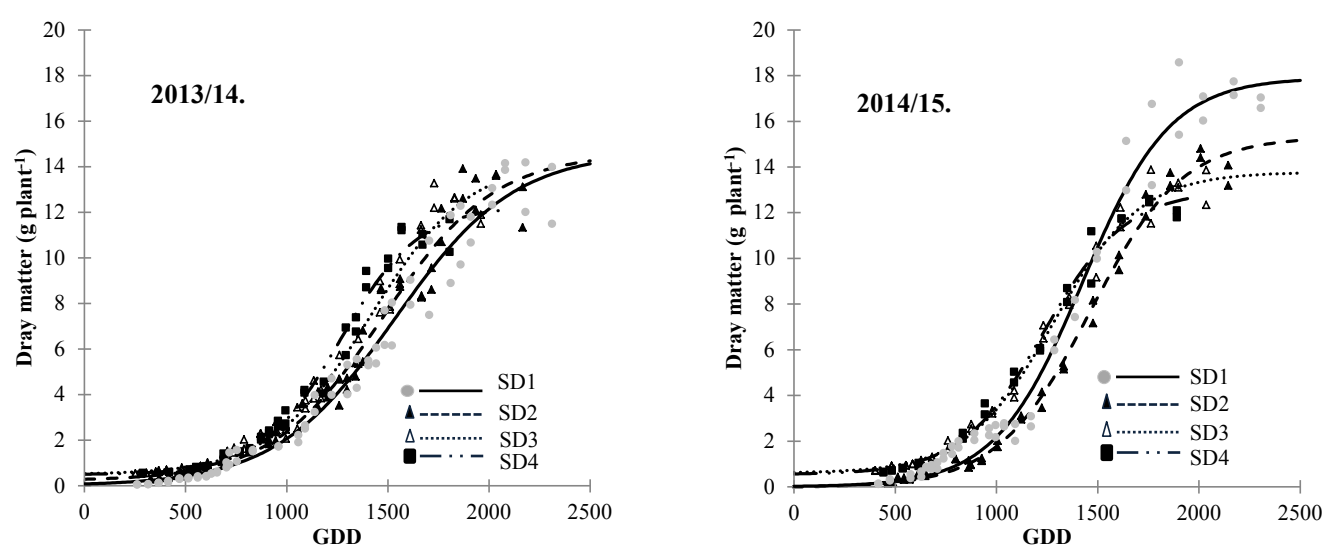

Figure 2. Patterns of biomass accumulation in barley for four sowing dates in 2013/14 and 2014/15 Grafikon 2. Akumulacija suve materije kasnostasnih sorti ječma sejanih u 2013/14. i 2014/15. u četiri roka setve 
Maximum value of plant dry matter $\left(\mathrm{y}_{\max }\right)$ varied between growing seasons. In the second growing season (2014/15), plants accumulated more dry matter in each sowing date than in the first season (2013/14). Season 2014/15 was characterized by a higher amount of winter precipitation that allowed increased plant growth in spring and higher accumulation of dry matter. Sowing date (SD) also had an influence on plant dry matter. In 2013/14, plants dry matter decreased from $14.6 \mathrm{~g}$ per plant (SD1) to $12.5 \mathrm{~g}$ per plant (SD4), while in the following season the dry matter of plants in SD1 was $17.9 \mathrm{~g}$ per plant and in SD4 $12.8 \mathrm{~g}$ per plant.

In the first growing season, dry matter reduction did not follow the linear trend, and there was no significant difference in plant dry matter among the first three SDs. The absence of a significant difference between these SDs was probably due to lower soil moisture content in early October, which reduced the dif- ference in the emergence date. As a result of early sowing, plants were more developed and tolerant to negative effects of low temperatures as the winter started. In spring, plants from earlier sowing produced more aboveground dry matter, mainly as a result of an increased photosynthetic area (Andarzian et al., 2014). Also, early sowing allowed a higher dry matter accumulation during the pre-anthesis period that can be translocated in the grain and mitigate the negative effects of the environmental factors (Mirosavljević et al., 2015).

The differences between SDs can be observed in Figure 2 through the modification of the curve shape. By shifting the sowing date from SD1 to SD4, the thermal time needed to reach the maximum value of plant dry matter $\left(\mathrm{x}_{\max }\right)$ decreased from 2393 to 1786 GDD in 2013/14, and from 2062 to 1833 GDD in 2014/15 (Table 1). By prolonging the growing season, early sowing increased radiation interception by

Table1. Coefficient of determination and values of logistic curve parameters in barley under four sowing dates in 2013/14 and 2014/15

Tabela 1. Vrednosti bioloških pokazatelja logističke krive kod sorti ječma sejanih u četiri roka u sezonama 2013/14. i 2014/15.

\begin{tabular}{ccccccc}
\hline $\begin{array}{c}\text { Growing } \\
\text { season }\end{array}$ & Sowing date & $\mathrm{R}^{2}$ & $\begin{array}{c}\mathrm{y}_{\max } \\
\left(\mathrm{g} \mathrm{plants}^{-1}\right)\end{array}$ & $\begin{array}{c}\mathrm{x}_{\max } \\
(\mathrm{GDD})\end{array}$ & $\begin{array}{c}\mathrm{DUR} \\
(\mathrm{GDD})\end{array}$ & $\begin{array}{c}\mathrm{Cm}^{-1} \\
\left(\mathrm{mg} \mathrm{plants}^{-1} \mathrm{GDD}^{-1}\right)\end{array}$ \\
\hline \multirow{3}{*}{$2013 / 14$} & $\mathrm{SD} 1$ & 0.97 & $14.6^{\mathrm{a}}$ & $2393^{\mathrm{a}}$ & $1174^{\mathrm{a}}$ & $6.5^{\mathrm{c}}$ \\
& $\mathrm{SD} 2$ & 0.97 & $15.0^{\mathrm{a}}$ & $2291^{\mathrm{ab}}$ & $1107^{\mathrm{a}}$ & $7.1^{\mathrm{bc}}$ \\
& $\mathrm{SD} 3$ & 0.98 & $14.6^{\mathrm{a}}$ & $2121^{\mathrm{b}}$ & $969^{\mathrm{b}}$ & $8.8^{\mathrm{b}}$ \\
& $\mathrm{SD} 4$ & 0.98 & $12.5^{\mathrm{b}}$ & $1786^{\mathrm{c}}$ & $755^{\mathrm{c}}$ & $12.7^{\mathrm{a}}$ \\
\hline \multirow{2}{*}{$2014 / 15$} & $\mathrm{SD} 1$ & 0.95 & $17.9^{\mathrm{a}}$ & $2062^{\mathrm{a}}$ & $867^{\mathrm{ab}}$ & $7.6^{\mathrm{b}}$ \\
& $\mathrm{SD} 2$ & 0.98 & $15.3^{\mathrm{ab}}$ & $2127^{\mathrm{a}}$ & $906^{\mathrm{a}}$ & $10.5^{\mathrm{a}}$ \\
& $\mathrm{SD} 3$ & 0.98 & $13.6^{\mathrm{b}}$ & $1910^{\mathrm{a}}$ & $859^{\mathrm{ab}}$ & $10.2^{\mathrm{a}}$ \\
& $\mathrm{SD} 4$ & 0.98 & $12.8^{\mathrm{b}}$ & $1833^{\mathrm{a}}$ & $819^{\mathrm{b}}$ & $10.8^{\mathrm{a}}$ \\
\hline
\end{tabular}

"Different letters represent significant difference between cultivars $(\mathrm{p}<0.05)$

$\mathrm{y}_{\max }$ - the maximum value of plant dry weight, $\mathrm{x}_{\max }$ - thermal time needed to reach $\mathrm{y}_{\max }$, DUR - the duration of exponential growth and $\mathrm{Cm}$ - maximum crop growth rate

$\mathrm{y}_{\max }$ - maksimalna vrednost suve materije, $\mathrm{x}_{\max }$ - suma aktivnih temperatura od setve do maksimalne biomase, DUR - trajanje perioda eksponencijalnog rasta i Cm - maksimalna brzina rasta 
canopy and grain yields in different crops (McDonald et al., 2007). Additionally, delay in sowing date beyond the optimum one caused that grain filling period often occurred under conditions of increased temperatures and moisture deficit. Ehdai et al. (2008) stated that the reduction in wheat grain yield under drought conditions primarily resulted from the shortening of the maximum growth period, and the increase in the translocation of dry matter from the vegetative parts to the grain cannot compensate grain yield reduction.

According to the Figure 2, the exponential phase, which was characterized by accelerated plant growth, started after the initial lag phase. This period is one of the most important phases of dry matter accumulation and grain yield formation since during this period plants accumulate a higher portion of the total dry matter. Echarte et al. (2008) stated that during this period corn accumulated up to $75 \%$ of the final dry matter. The values of this parameter varied among the sowing dates. By delaying the sowing date, the value of this parameter significantly decreased. In 2013/14 the duration of exponential phase (DUR) was on average 755 GDD in SD4 and 1174 GDD in SD1. In the following seasons, some lower values of this parameter were recorded, with the lowest values being determined in SD4 (819 SAT). These results are in agreement with Yusoff (2012), who reported that prolonging the sowing period led to a shorter duration of exponential growth in the Italian rye-grass and oat.

Contrary to the duration of the exponential period, changes in the sowing date led to an increase in maximum crop growth rate $(\mathrm{Cm})$. The influence of the sowing date was more pronounced in 2013/14 than in 2014/15. By shifting the sowing date from late Septem- ber (SD1) to early November (SD4) in 2013/14, $\mathrm{Cm}$ increased from 6.5 to $12.7 \mathrm{mg}$ per plant $\mathrm{GDD}^{-1}$, while in the following season the increase in $\mathrm{Cm}$ was from 7.6 to $10.8 \mathrm{mg}$ per plant $\mathrm{GDD}^{-1}$. These results suggest that the shortening of the exponential period in late sowing was compensated by an increase in the growth rate. Bell et al. (2000) reported that dry matter accumulation during the exponential phase resulted from the maximum growth rate of the plants, and that there was a close relationship between maximum dry matter and maximum growth rate.

\section{Conclusion}

Dry matter accumulation of the above ground plant parts during the whole growing season was efficiently described by a typical sigmoidal equation in all sowing dates. Duration of the period to the maximum dry matter and the period of exponential growth increased in 2013/14. In the following season, plants were characterized by higher dry matter and maximum growth rates.

Late sowing in November led to a reduction in dry matter, the duration of the period to the maximum dry matter, and the increase in the maximum growth rate of plants. Based on this, it can be concluded that next to the appropriate cultivar selection, it is necessary to sow barley early so that plants can better adjust their development to the agro-ecological conditions.

\section{Acknowledgements}

This paper is a result of the project TR31066 "Modern breeding of small grains for present and future needs", supported by the Ministry of Education, Science and Technological Development of the Republic of Serbia. 


\section{References:}

Andarzian B, Hoogenboom G, Bannayan M, Shirali M, Andarzian B (2014): Determining optimum sowing date of wheat using CSM- CERES-Wheat model. J. Saudi. Soc. Agric. Sci. 14: 189-199.

Araus JL, Slafer GA, Royo C, Dolores Serret M (2008): Breeding for yield potential and stress adaptation in cereals. Crit. Rev. Plant. Sci. 27: 377-412.

Banjac B, Dimitrijević M, Petrović S, Mladenov V (2015): Stabilnost komponenti prinosa hlebne pšenice gajene na različitim tipovima zemljišta. Selekcija i semenarstvo 21: 81-92.

Bell GE, Danneberger TK, McMahon MJ (2000): Spectral irradiance available for turfgrass growth in sun and shade. Crop Sci. 40: 189-195.

Echarte L, Rothstein S, Tollenaar M (2008): The response of leaf photosynthesis and dry matter accumulation to nitrogen supply in an older and a newer maize hybrid. Crop Sci. 48: 656-665.

Ehdaie B, Waines JG (2001): Sowing date and nitrogen rate effects on dry matter and nitrogen partitioning in bread and durum wheat. Field Crops Res. 73: 47-61.

Ehdaie B, Alloush GA, Waines JG (2008): Genotypic variation in linear rate of grain growth and contribution of stem reserves to grain yield in wheat. Field Crops Res. 106: 34-43

Hyams DG (2010): CurveExpert Professional. CurveExpert software. http://www.curveexpert.net

InfoStat (2012): Infostat/Students version 2.0. Infostat/FCA Group. Córdoba's National University; Ed. Brujas, Córdoba, Argentina
McDonald GK, Hollaway KL, McMurray L (2007): Increasing plant density improves weed competition in lentils (Lens culinaris L.). Aust. J. Exp. Agric. 47: 48-56.

Malhi SS, Johnston AM, Schoenau JJ, Wang ZH, Vera CL (2007): Seasonal biomass accumulation and nutrient uptake of pea and lentil on a black chernozem soil in Saskatchewan. J. Plant Nutr. 30: 721737.

Mirosavljević M, Pržulj N, Momčilović V, Hristov N, Maksimović I (2015): Dry matter accumulation and remobilization in winter barley as affected by genotype and sowing date. Genetika 47(2): 751763.

Moustakas NK, Ntzanis H (2005): Dry matter accumulation and nutrient uptake in flue-cured tobacco (Nicotiana tabacum L.). Field Crops Res. 94: 1-13.

Munakamwe Z, McKenzie B, Hill G (2014): The effect of genotype and agronomic factors on crop growth and yield in field peas (Pisum sativum L.) as influenced by radiation interception and utilisation. Aus. J. Crop. Sci. 8(5): 680-688.

Panozzo JF, Eagles HA (1999): Rate and duration of grain filling and grain nitrogen accumulation of wheat cultivars grown in different environments. Aust. J. Agric. Res. 50: 1007-1015.

Petrović S, Dimitrijević M, Ljubičić N, Banjac B (2013): Nasleđivanje osobina klasa heksaploidne pšenice (Triticum aestivum L.). Selekcija i semenarstvo,19(1): 43-52.

Pržulj N, Momčilović V (2011): Značaj faze organogeneze formiranje klasića u biologiji prinosa ozimog dvoredog ječma. Ratarstvo i povrtarstvo 48(1): 37-48 
Setiyono TD, Weiss A, Specht JK, Cassman KG, Dobermann A (2008): Leaf area index simulation in soybean grown under near-optimal conditions. Field Crops Res. 108: 82-92.

Subedi KD, Ma BL, Xue AG (2007): Planting date and nitrogen effects on grain yield and protein content of spring wheat. Crop Sci. 47: 36-44.

Turner NC (1997): Further progress in crop water relations. Adv. Agron. 58: 293338.

van den Boogaard R, Veneklaas EJ, Peacock JM, Lambers H (1996): Yield and water use of wheat (Triticum aestivum L.) in a Mediterranean environment: cultivar differences and sowing density effects. Plant Soil. 181: 251-262.

Villegas D, Aparicio N, Blanco R, Royo C (2001): Biomass accumulation and main stem elongation of durum wheat grown under Mediterranean conditions. Ann. Bot. 88: 617-627.

White JW, Kimball BA, Wall GW, Ottman MJ, Hunt LA (2011): Responses of time of anthesis and maturity to sowing dates and infrared warming in spring wheat. Field Crops Res. 124: 213-222.
White WJ, Kimball BA, Wall GW, Ottman MJ (2012): Cardinal temperatures for wheat leaf appearance as assessed from varied sowing dates and infrared warming. Field Crop Res. 137: 213-220.

Yang GZ, Tang HY, Tong J, Nie YC, Zhang XL (2011): Responses of cotton growth, yield, and biomass to nitrogen split application ratio. Eur. J. Agron. 35: 164170.

Yin X, Stam P, Kropff MJ, Schapendonk AHCM (2003): Crop modeling, qtl mapping, and their complementary role in plant breeding. Agron. J. 95: 90-98.

Yusoff MM (2012): Physiological and environmental constraints to winter forage crops production. Doctoral dissertation. Lincoln University, Canterbury, New Zealand.

Zhou B, Sanz-Sáez A, Elazab A, Shen T, Sánchez-Bragado R, Bort J, Serret MD, Araus JL (2014): Physiological traits contributed to the recent increase in yield potential of winter wheat from Henan Province, China. J. Integr. Plant. Biol. 56: 492-504. 


\title{
ROK SETVE I AKUMULACIJA SUVE MATERIJE KOD OZIMOG JEČMA
}

\author{
Milan Mirosavljević, Vojislava Momčilović, Ivana Maksimović, \\ Marina Putnik-Delić, Ljiljana Brbaklić, Novo Pržulj
}

\begin{abstract}
Sažetak
Produkcija biomase je jedan od najboljih pokazatelja uticaja genotipa i faktora sredine na razviće useva. Cilj istraživanja je bio ispitivanje akumulacije suve materije nadzemnog dela biljaka ječma i promene parametara krive u uslovima različitih rokova setve i vegetacionih sezona. Poljski ogled sa ozimim ječmom je izveden tokom dve uzastopne sezone i četiri roka setve. Rezultati ovog istraživanja pokazuju da je akumulacija suve materije u obe sezone ispitivanja pratila tipičan sigmoidni obrazac i bila dobro objašnjena logističkom jednačinom. Rok setve je imao značajan uticaj na posmatrane parametre. Odlaganje setve sa kraja oktobra do prve dekade novembra vodilo je ka značajnom smanjenju maksimalne biomase, trajanja perioda do maksimalne biomase i trajanja eksponencijalnog rasta. U sezoni 2013/14. u zavisnosti od roka setve biomasa je varirala od 12,5 do15,0 g po biljci, dok se naredne sezone kretala između 12,8 i 17,9 g po biljci. Pored toga, pomeranje roka setve dovelo je do značajnog povećanja maksimalne brzine rasta biljaka. Dati rezultati pokazuju da je pored pravilnog odabira sorte, rana setva ozimog ječma neophodna za ostvarivanje visoke akumulacije suve materije koja predstavlja jedan od glavnih preduslova za postizanje visokih prinosa.
\end{abstract}

Ključne reči: biomasa, Hordeum vulgare, logistička kriva, vreme setve

Primljen: 2.03.2018.

Prihvaćen: 4.04.2018. 